\title{
Pengaruh Literasi Keuangan terhadap Keputusan Investasi The Jak Mania pada Rencana Initial Public Offering PT. Persija Jakarta
}

\author{
Thomas Mahendra* \\ Program Studi Magister Manajemen, Sekolah Tinggi Manajemen PPM \\ Jl. Menteng Raya No.9, Kb. Sirih, Kec. Menteng, Kota Jakarta Pusat, Jakarta, Indonesia \\ thooom20@gmail.com \\ Aries Heru Prasetyo \\ Program Studi Magister Manajemen, Sekolah Tinggi Manajemen PPM \\ Jl. Menteng Raya No.9, Kb. Sirih, Kec. Menteng, Kota Jakarta Pusat, Jakarta, Indonesia \\ justzhongshan@gmail.com
}

Diterima: 09-02-2021

Disetujui: 16-06-2021

Dipublikasi: 30-06-2021

\begin{abstract}
ABSTRAK
Perkembangan olahraga sepak bola terutama di Indonesia mempunyai cara lain dalam memperoleh dana selain dari penjualan, klub sepak bola di Indonesia mempunyai rencana untuk terdaftar di Bursa Efek Indonesia. Persija Jakarta mempunyai rencana melakukan Initial Public Offering dalam waktu dekat ini. The Jak Mania adalah suporter klub sepak bola Persija Jakarta. The Jak Mania harus mempunyai keputusan investasi yang baik jika ingin melakukan investasi khususnya pada saham Persija, sebab investasi tersebut akan menghasilkan hasil yang baik. Menurut OECD literasi keuangan adalah kombinasi dari awareness, knowledge, skill, attitude, dan behaviour yang dibutuhkan untuk mendapatkan pengambilan keputusan finansial dan mencapai keuangan yang sejahtera. Penelitian ini bertujuan untuk mengetahui apakah literasi keuangan dengan indikator financial knowledge, financial attitude, dan financial behaviour berpengaruh positif dan signifikan terhadap keputusan investasi Initial Public Offering Persija Jaya Jakarta dengan sampel yaitu The Jak Mania. Penelitian ini dilakukan menggunakan media kuesioner dengan metode teknik purposive sampling dengan jumlah responden 232 . Hasil penelitian ini diketahui bahwa financial knowledge, financial attitude, dan financial behaviour berpengaruh positif dan signifikan terhadap keputusan investasi The Jak Mania pada rencana Initial Public Offering PT Persija Jaya Jakarta.
\end{abstract}

Kata Kunci:

The Jak Mania; Literasi Keuangan; Financial Knowledge; Financial Attitude; Financial Behavior; Keputusan Investas.

\begin{abstract}
The evolution of football in Indonesia have another way to gain fund apart from the sales, football club in Indonesia have its own plan to be listed on The Indonesia Stock Exchange. Persija Jakarta have a plan to do an Initial Public Offering in the near future. The Jak Mania is the supporter of the Persija Jakarta Football Club. The Jak Mania must have a good investment decision if they want to invest in the Persija shares, because the investment will produce a good return. The OECD said that the financial literation is the combination of awareness, knowledge, skill, attitude, and behavior that needed to get financial decision and achieve a good individual financial being. This research is aim to know is the financial literation with indicator financial knowledge, financial attitude, and financial behavior have a positive and significant influences to the investment decision on the Initial Public Offering Persija Jaya Jakarta with The Jak Mania as the sample. This Research used questionnaire as the method with purposive sampling technique with 232 respondents. The result of this research is knowing that financial knowledge, financial attitude, and financial behavior have a positive and significant influences to investment decision of The Jak Mania on Initial Public Offering of PT Persija Jaya Jakarta.
\end{abstract}

Keywords:

The Jak Mania; Financial Literacy; Financial Knowledge; Financial Attitude; Financial Behavior; Investment Decision.. 


\section{PENDAHULUAN}

Sepak bola adalah olahraga populer di dunia dan olahraga yang paling diminati.Sepak bola disaksikan oleh penikmat sepak bola dengan cara mendatangi langsung stadion, menonton televisi, dan melalui internet dengan cara streaming pertandingan sepak bola. Hal ini membantu pemasukan klub sepak bola melalui penjualan tiket, hak siar pertandingan, merchandise club, dan hadiah juara jika klub tersebut mampu berprestasi. Jumlah penonton yang banyak membuat banyak perusahaan ingin mensponsori klub sepak bola dengan feedback pencantuman nama perusahaan seperti di jersey klub, board lapangan, sampai unggahan media sosial klub tersebut. Sepak bola sudah menjadi bisnis yang menguntungkan berbagai pihak. Klub sepak bola perlu berkembang terus menerus untuk meningkatkan performa tim, dengan hal itu banyak faktor yang perlu diperbaiki seperti fasilitas latihan, pemain berpengalaman, stadion, akomodasi, dll. Selain dari sponsor, klub sepak bola bisa mendapatkan dana melalui bursa efek dengan melakukan Initial Public Offering yang dimana klub sepak bola melepas sahamnya ke publik untuk diperjual-belikan kepada publik. Terdapat klub sepak bola dalam negeri yaitu dan Bali United (BOLA) dan banyak klub sepak bola eropa yang salah satu contohnya adalah Borussia Dortmund. Borussia Dortmund melakukan IPO dengan tujuan meningkatkan prestasi dengan cara mendapatkan pemain yang berkualitas tinggi dan ekspansi stadion. Hal tersebut membuat klub menjadi sukses di Jerman serta di kancah Internasional. Hal ini membuat revenue Borussia Dortmund menjadi meningkat yang membuat finansial klub menjadi sejahtera (Büchler \& Jücke, 2012).

Dengan adanya Bali United sebagai klub pertama yang berhasil melakukan IPO pada tahun 2019 yang menjual sahamnya dengan mendapatkan dana sebesar 350 miliar. Persija Jakarta juga ingin melakukan hal tersebut dan ingin melampaui keberhasilan Bali United (Paulus, 2020) Menjelaskan Persija sangat optimis IPO mereka akan lebih sukses dibandingkan Bali United yang lebih dulu melakukan IPO karena lebih besarnya pendukung Persija dan juga nilai Persija yang dinilai besar karena salah satu pendiri PSSI. Hal ini membuat banyak keuntungan Persija Jakarta untuk mendapatkan dana untuk memperbaiki klub tersebut agar menjadi yang terbaik. Persija yang bersiap melakukan penjualan saham ke publik melalui bursa efek perlu diketahui oleh The Jak Mania. The Jak mania adalah suporter sepak bola yang terkenal loyal oleh masyarakat di Indonesia, hampir semua pertandingan kandang Persija Jakarta didatangi The Jak Mania dengan kondisi stadion yang penuh dengan rata-rata 24.303 penonton per pertandingan dan 70.306 penonton terbanyak pada satu pertandingan Persija Jakarta (IDN TIMES, 2019). Jika The Jak Mania mengetahui berita tersebut maka The Jak Mania perlu mempunyai literasi keuangan agar membeli keuangan dengan cara menganggarkan uang yang dimilikinya. The Jak Mania perlu mempunyai financial knowledge diperlukan untuk mengetahui nilai uang dari waktu, mengetahui risiko investasi, karakteristik saham, dan juga strategi pada membeli saham. Oleh karena itu The Jak Mania perlu mempunyai pengetahuan ekonomi yang baik dan pengelolaan keuangan yang baik agar bisa mengalokasikan uang tersebut untuk membeli saham Persija Jakarta saat go public. Pengetahuan tentang ekonomi sangat dibutuhkan untuk $\underline{\text { mengetahui IPO pada setiap perusahaan dan khususnya tentang literasi keuangan sebab jika pengelolaan }}$ 
keuangan yang buruk akan membuat kondisi setiap individu yang tidak memiliki pengelolaan yang baik yang akan membuat kehidupan seseorang akan menjadi sulit.

Financial attitude dibutuhkan dalam melakukan investasi karena sikap setiap individu dalam menghasilkan uang, sikap mereka dalam mencatat pemasukkan dan keuangan individu, menghasilkan uang, dan juga membeli barang yang dibutuhkan bukan diinginkan menjadi faktor yang mempengaruhi sikap individu agar tetap konsisten dalam investasi saham. Jika sikap dalam mengelola, memperlakukannya, dan menggunakannya dengan baik, maka ini akan membantu seseorang agar baik dalam mengambil sikap keputusannya terhadap uang. Jika The Jak Mania tidak mempunyai pengetahuan ekonomi mengenai membeli saham, tidak akan bisa membeli saham Persija serta mendapatkan keuntungan melalui saham yang diperoleh dari pergerakan harga saham yang dipengaruhi oleh permintaan serta kondisi ekonomi makro dan tidak bisa dapat bersuara di Rapat Umum Pemegang Saham seperti pemilihan manajer/pelatih klub Persija. Serta The Jak perlu mempunyai persepsi, penilaian, dan keadaan keuangan agar bisa mempunyai informasi yang dimiliki pada keuangan individu setiap The Jak Mania agar memiliki informasi untuk membuat keputusan investasi yang baik. Dalam hal ini diketahui keadaan, penilaian, dan pendapat terhadap uang yang diterapkan seseorang atau diaplikasikan dalam sikap seseorang.

Financial behaviour adalah salah satu indikator dari literasi keuangan. Sebab perilaku setiap individu untuk tetap melakukan pembayaran, membuat pengeluaran lebih kecil, dan juga membayar kewajiban setiap individu adalah perilaku-perilaku yang perlu dilakukan dan konsisten agar pembelian pada saham bisa dilakukan. Perilaku seseorang dalam memperlakukan keuangan, mengelola keuangan, dan menggunakannya dengan rasional agar dana yang dimiliki bisa dipakai untuk investasi. Perilaku yang dimiliki oleh seseorang dalam mengelola keuangan membentuk finansial mereka dan kesejahteraan mereka dalam jangka pendek serta dalam jangka panjang. Perilaku yang dimiliki oleh seseorang dalam mengelola keuangan membentuk finansial mereka dan kesejahteraan mereka dalam jangka pendek serta dalam jangka panjang. Dalam perilaku keuangan terdapat faktor-faktor pendukung agar memaksimal kesejahteraan mereka seperti menganggarkan keuangan, tanggung jawab dalam pengambilan keputusan, membayar tagihan seperti air, listrik, pajak, dll tepat pada waktunya, dan mempertimbangkan hal yang ingin dibeli sebelum membeli. Dalam hal ini diketahui keadaan, penilaian, dan pendapat terhadap uang yang diterapkan seseorang atau diaplikasikan dalam sikap seseorang. Jika sikap dalam mengelola, memperlakukannya, dan menggunakannya dengan baik, maka ini akan membantu seseorang agar baik dalam mengambil sikap keputusannya terhadap uang. Jika ketiga indikator tersebut dapat berjalan dengan baik, maka The Jak Mania dapat melakukan penganggaran sejak lama agar bisa mendapatkan saham IPO Persija Jakarta dengan uang tersebut.

Pengetahuan tentang investasi diperlukan dalam hal membeli saham, karena jika tidak mengetahui pengetahuan tentang saham maka daya tarik untuk membeli saham tidak dapat terlaksana. Investor yang masih baru dalam berinvestasi sangat mempertimbangkan semua faktor yang berhubungan dengan keputusan investasinya dengan pengetahuan yang minim. Sedangkan semakin 
lama seorang investor melakukan investasi maka semakin berkurang faktor yang dipertimbangkan sebab semakin lama semakin banyak pengalaman sehingga keputusan investasi lebih banyak berdasarkan pengalaman (Utami \& Kartini, 2016). Oleh karena itu Persija perlu memastikan pendukung klub sepak bola tersebut mempunyai pengetahuan tentang membeli saham. Pengetahuan yang diperlukan adalah pengetahuan investasi karena penting untuk menentukan tujuan investasi, mengetahui resiko, keuntungan, legal/ tidaknya perusahaan tersebut, keadaan perusahaan tersebut melalui profile yang tersedia di bursa efek dan juga berita-berita yang memberitakan perusahaan tersebut, karena berita juga mempengaruhi harga saham dari perusahaan.

Dengan adanya ketiga indikator tersebut peneliti akan melakukan penelitian tentang literasi keuangan kepada The Jak Mania yaitu pendukung sepak bola Persija Jakarta dalam membuat keputusan dalam membeli saham. Sebab, peneliti ingin mengetahui apakah literasi keuangan dengan ketiga indikator tersebut yang dijalankan dengan baik dan buruk akan mempengaruhi pendukung Persija Jakarta yaitu The Jak Mania. Untuk itu peneliti mengambil judul penelitian yaitu Pengaruh Literasi Keuangan Terhadap Keputusan Investasi The Jak Mania pada Initial Public Offering PT Persija Jaya Jakarta.

\section{Rumusan Masalah}

Adapun rumusan masalah yang diajukan dalam penelitian ini adalah:

1. Apakah financial knowledge berpengaruh positif dan signifikan terhadap keputusan investasi pada The Jak Mania pada rencana Initial Public Offering PT Persija Jaya Jakarta?

2. Apakah financial attitude berpengaruh positif dan signifikan terhadap keputusan investasi pada The Jak Mania pada rencana Initial Public Offering PT Persija Jaya Jakarta?

3. Apakah financial behaviour berpengaruh positif dan signifikan terhadap keputusan investasi pada The Jak Mania pada rencana Initial Public Offering PT Persija Jaya Jakarta?

\section{Literasi Keuangan}

Menurut Otoritas Jasa Keuangan (2017), Literasi Keuangan adalah rangkaian proses atau aktivitas untuk meningkatkan pengetahuan (knowledge), keyakinan (confidence), keterampilan (skill) konsumen dan masyarakat luas sehingga mereka mampu mengelola keuangan dengan lebih baik. Pengetahuan, keterampilan, dan keyakinan keuangan yang dimiliki oleh seorang individu berpengaruh terhadap sikap dan perilaku keuangannya. Peningkatan pengetahuan yang dimiliki seseorang dapat berdampak pada partisipasi yang aktif dalam kegiatan terkait keuangan, serta perilaku keuangan yang lebih positif pada seorang individu. Lusardi \& Mitchell dalam (Rasyid, 2012) menyatakan literasi keuangan dapat diartikan sebagai pengetahuan keuangan, dengan mencapai tujuan kesejahteraan. Menurut OJK, Literasi Keuangan memiliki tujuan jangka panjang bagi seluruh golongan masyarakat, yaitu:

1. Meningkatkan literasi seseorang yang sebelumnya less literate atau not literate menjadi well literate. 
2. Meningkatkan jumlah pengguna produk dan layanan jasa keuangan. Agar masyarakat luas dapat menentukan produk dan layanan jasa keuangan yang sesuai dengan kebutuhan, masyarakat harus memahami dengan benar manfaat dan risiko, mengetahui hak dan kewajiban serta meyakini bahwa produk dan layanan jasa keuangan yang dipilih dapat meningkatkan kesejahteraan masyarakat. Bagi masyarakat, Literasi Keuangan memberikan manfaat yang besar, seperti:

a. Mampu memilih dan memanfaatkan produk dan layanan jasa keuangan yang sesuai kebutuhan; memiliki kemampuan dalam melakukan perencanaan keuangan dengan lebih baik.

b. Terhindar dari aktivitas investasi pada instrumen keuangan yang tidak jelas. Mendapatkan pemahaman mengenai manfaat dan risiko produk dan layanan jasa keuangan.

Literasi Keuangan juga memberikan manfaat yang besar bagi sektor jasa keuangan. Lembaga keuangan dan masyarakat saling membutuhkan satu sama lain sehingga semakin tinggi tingkat Literasi Keuangan masyarakat, maka semakin banyak masyarakat yang akan memanfaatkan produk dan layanan jasa keuangan

\section{Indikator Literasi Keuangan}

\section{Financial knowledge}

Wagland and Taylor (2009) mengatakan bahwa pengetahuan keuangan pribadi tergantung bagaimana seseorang dapat mengatur pendapatan dan pengeluaran serta memahami konsep dan menerapkannya dalam kehidupan sehari-hari. Konsep-konsep keuangan penting bagi seseorang untuk menginvestasikan dan mengelola dananya untuk meningkatkan kekayaan.

\section{Financial Attitude}

Menurut Besri (2018), financial attitude adalah situasi, pendapat seseorang terhadap dana yang diimplementasikan ke dalam sikap.

\section{Financial behaviour}

Tindakan dan perilaku konsumen itulah yang akhirnya membentuk situasi keuangan mereka dan kesejahteraan baik dalam jangka pendek maupun jangka panjang. Beberapa jenis perilaku, seperti menunda pembayaran kartu kredit untuk mengurangi kekurangan pendapatan berdampak negatif pada keuangan individu dan kesejahteraan finansial mereka. Pada waktu bersamaan, digitalisasi keuangan yang meningkat mengubah interaksi konsumen dengan cara beragam (baru) penyedia keuangan. Meningkatkan kebutuhan untuk memahami perilaku dan mengidentifikasi tren yang muncul (OECD, 2017). Oleh karena itu penting untuk mencoba menilai perilaku keuangan dalam survei literasi keuangan.

\section{Keputusan Investasi}

Hal yang paling mendasar dalam keputusan berinvestasi adalah return dan risk. Karena pemahaman hubungan antara keuntungan (Return) yang diharapkan dengan resiko (Risk) yang diterima 
dari investasi yang dilakukannya adalah merupakan hubungan yang searah (Linier). Artinya semakin besar keuntungan yang diharapkan maka semakin besar pula resiko yang harus dihadapinya. Sehingga bagi para investor agar dapat meminimalkan resiko berinvestasi perlu pemahaman secara rasional dan berhati-hati dalam proses pengambilan keputusan (Pratiwi \& Prijati, 2015).

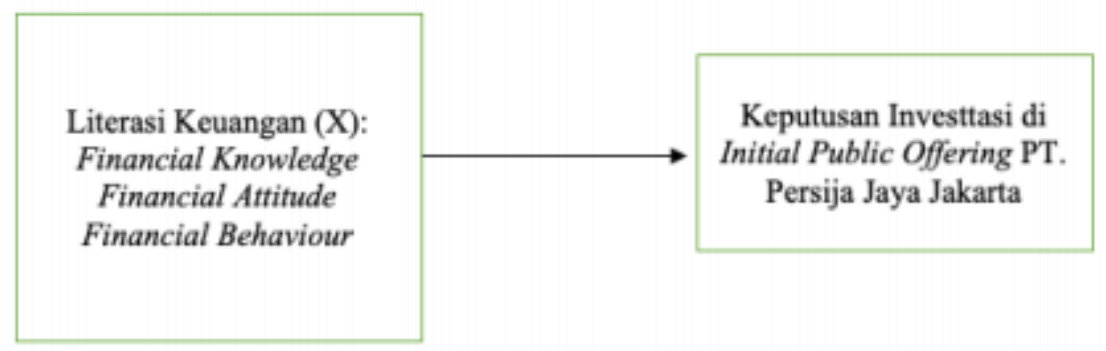

Gambar 1. Kerangka Konseptual Penelitian

Berdasarkan uraian di atas, maka dapat dirumuskan hipotesisnya yaitu:

H1 : Financial knowledge berpengaruh positif dan signifikan terhadap keputusan investasi The Jak Mania pada Initial Public Offering PT Persija Jaya Jakarta.

H2 : Financial attitude berpengaruh positif dan signifikan terhadap keputusan investasi The Jak Mania pada Initial Public Offering PT Persija Jaya Jakarta.

H3 : Financial behaviour berpengaruh positif dan signifikan terhadap keputusan investasi The Jak Mania pada Initial Public Offering PT Persija Jaya Jakarta

\section{METODE RISET}

Penelitian ini merupakan penelitian jenis kausal dengan pendekatan kuantitatif. Penelitian kausal komparatif merupakan penelitian yang mencari informasi terjadinya hubungan sebab akibat dan peneliti berusaha melacak kembali hubungan sebab akibat tersebut (Sukardi, 2003).Populasi adalah kumpulan dari seluruh unit-unit pengamatan yang menjadi penelitian dalam suatu penelitian survei (Asra \& Prasetyo,2015). Populasi dalam penelitian ini adalah pendukung Persija Jakarta / The Jak Mania yang mengikuti informasi tentang Persija Jakarta dan menonton Persija Jakarta langsung ke stadion / melalui TV / internet yang menyediakan pertandingan Persija Jakarta yang populasinya tidak diketahui.

Sampel adalah sebagian atau wakil populasi yang dipilih. Jika hanya akan meneliti sebagian dari populasi, maka penelitian tersebut disebut penelitian sampel (Arikunto, 2006). Teknik pengambilan sampel yang digunakan adalah teknik non probability sampling, menurut Sugiyono (2015) teknik nonprobability sampling yaitu teknik pengambilan sampel yang tidak memberi peluang, atau kesempatan sama bagi setiap unsur, atau anggota populasi untuk dipilih menjadi sampel.

Teknik purposive sampling dilakukan untuk mendapatkan sampel yang sesuai dengan kebutuhan penelitian. Sampel pencarian data uji coba melalui angket/kuesioner dalam penelitian ini. Dimana sampel yang dipilih berdasarkan karakteristiknya. Teknik ini dipilih karena populasi dan sampel yang diambil memiliki karakteristik tertentu. Karakteristik tersebut yaitu: 
1. Minimal berusia 18 tahun.

2. Berdomisili di DKI Jakarta

3. Mengikuti perkembangan Persija Jakarta dalam kurun waktu satu tahun terakhir.

4. The Jak Mania yang menonton pertandingan Persija Jakarta pada musim 2018/2019 dengan langsung datang ke stadion atau menonton pertandingan Persija melalui televisi lebih dari 5 pertandingan dalam musim tersebut. Apabila populasi tidak diketahui, penentuan jumlah sampel pada penelitian ini adalah 232. Oleh karena itu, peneliti akan menyebarkan kuesioner kepada 232 sampel yang telah ditentukan dengan karakteristik dalam teknik purposive agar sampling yang dilakukan sesuai dengan apa yang dibutuhkan oleh peneliti.

\section{Pengumpulan Data}

Penelitian ini menggunakan data primer. Data yang dikumpulkan menggunakan Teknik kuesioner, yaitu memberikan pernyataan tertulis kepada responden. Setelah itu, responden yang telah ditentukan kriterianya akan memberikan tanggapan atas pernyataan dari kuesioner yang diberikan. Kuesioner yang diberikan kepada responden menggunakan skala likert. Kesahihan dalam suatu penelitian sangat ditentukan oleh alat ukur yang digunakan. Maka dalam mengatasi hal tersebut diperlukan dua macam pengujian yaitu test of validity (uji validitas atau kesahihan) dan test of reliability (uji kehandanlan).

\section{Metode Analisis Data}

Metode analisis data menggunakan uji validitas .Menurut Sugiyono (2010) uji validitas dan dan reliabilitas membutuhkan 32 data pertama dari kuesioner. Maka dari itu berdasarkan $r$ tabel. dengan tingkat degree of freedom 30 (n-2) dan tingkat signifikansi 0,05 maka ditetapkan nilai $r$ tabel sebesar 0,296. Uji relibilitas menunjukkan sejauh mana suatu alat ukur dapat diandalkan atau dipercaya untuk mengukur suatu objek yang akan diukur, dan untuk melihat konsistensi alat ukur dalam mengukur gejala yang sama (Sugiyono, 2007). Semakin besar nilai $\alpha$ (alpha), maka semakin besar juga reliabilitasnya.

\section{Analisis Deskriptif}

Statistik deskriptif merupakan suatu metode dalam menganalisis data kuantitatif, sehingga diperoleh gambaran yang teratur mengenai suatu kegiatan (Ghozali, 2009). Ukuran yang digunakan dalam deskripsi antara lain: frekuensi, tendensi sentral (mean), dan dispersi (maksimum, minimum dan standar deviasi).

\section{Uji Asumsi Klasik}

Uji asumsi klasik digunakan untuk menguji, apakah model regresi yang digunakan dalam penelitian ini layak diuji atau tidak. 


\section{Uji Normalitas}

Menurut Ghozali (2016) uji normalitas dilakukan untuk menguji apakah pada suatu model regresi, suatu variabel independen dan variabel dependen ataupun keduanya mempunyai distribusi normal atau tidak normal. Apabila suatu variabel tidak berdistribusi secara normal, maka hasil uji statistik akan mengalami penurunan. Pada uji normalitas data dapat dilakukan dengan menggunakan uji One Sample Kolmogorov Smirnov yaitu dengan ketentuan apabila nilai signifikansi diatas 5\% atau 0,05 maka data memiliki distribusi normal. Sedangkan jika hasil uji One Sample Kolmogorov Smirnov menghasilkan nilai signifikan dibawah 5\% atau 0,05 maka data tidak memiliki distribusi normal.

\section{Uji Multikolinieritas}

Menurut Ghozali (2016) pada pengujian multikolinearitas bertujuan untuk mengetahui apakah model regresi ditemukan adanya korelasi antar variabel independen atau variabel bebas. Efek dari multikolinearitas ini adalah menyebabkan tingginya variabel pada sampel. Hal tersebut berarti standar error besar, akibatnya ketika koefisien diuji, t-hitung akan bernilai kecil dari t-tabel. Hal ini menunjukkan tidak adanya hubungan linear antara variabel independen yang dipengaruhi dengan variabel dependen.

Untuk menemukan terdapat atau tidaknya dari nilai toleransi dan nilai variance inflation factor (VIF). Nilai Tolerance mengukur variabilitas dari variabel bebas yang terpilih yang tidak dapat dijelaskan oleh variabel bebas lainnya. Jadi nilai tolerance rendah sama dengan nilai VIF tinggi, dikarenakan $\mathrm{VIF}=1 /$ tolerance, dan menunjukkan terdapat multikolinearitas yang tinggi. Nilai cut off yang digunakan adalah untuk nilai tolerance 0,10 atau nilai VIF dibawah angka 10.

\section{Uji Heteroskedastisitas}

Uji ini bertujuan untuk melakukan uji apakah pada sebuah model regresi terjadi ketidaknyamanan varian dari residual dalam satu pengamatan ke pengamatan lainnya. Apabila varian berbeda, disebut heteroskedastisitas. Salah satu cara untuk mengetahui ada tidaknya heteroskedastisitas pada suatu model regresi linier berganda, yaitu dengan melihat grafik scatterplot atau dari nilai prediksi variabel terikat yaitu SRESID dengan residual error yaitu ZPRED. Apabila tidak terdapat pola tertentu dan tidak menyebar diatas maupun dibawah angka nol pada sumbu y, maka dapat disimpulkan tidak terjadi heteroskedastisitas. Untuk model penelitian yang baik adalah yang tidak terdapat heteroskedastisitas (Ghozali, 2016).

\section{Uji Hipotesis}

\section{Uji Signifikansi Parameter Individual (Uji Statistik t)}

Uji statistik t pada dasarnya menunjukkan seberapa jauh pengaruh satu variabel penjelas (independen) secara individual dalam menerangkan variasi variabel dependen. Uji t mempunyai nilai signifikansi $\alpha=5 \%$. Kriteria pengujian hipotesis dengan menggunakan uji statistik t adalah jika nilai signifikansi $\mathrm{t}(\mathrm{p}$ value $)<0,05$, maka hipotesis alternatif diterima, yang menyatakan bahwa 
suatu variabel independen secara individual dan signifikan mempengaruhi variabel dependen (Ghozali, 2016).

\section{Uji Statistik F}

Uji statistik F mengukur goodness of fit, yaitu ketepatan fungsi regresi sampel dalam menaksir nilai aktual. Jika nilai signifikansi $\mathrm{F}<0,05$, maka model regresi dapat digunakan untuk memprediksi variabel independen. Uji statistik $F$ juga menunjukkan apakah semua variabel independen atau bebas yang dimasukkan dalam model mempunyai pengaruh secara bersama-sama terhadap variabel dependen. Uji statistik F mempunyai signifikansi 0,05 (Ghozali, 2016). Kriteria pengujian hipotesis dengan menggunakan statistik $\mathrm{F}$ adalah jika nilai signifikansi $\mathrm{F}<0,05$, maka hipotesis alternatif diterima, yang menyatakan bahwa semua variabel independen secara simultan dan signifikan mempengaruhi variabel dependen (Ghozali, 2016).

\section{Koefisien Determinasi ( Adjusted $\mathbf{R}_{2}$ )}

Menurut Ghozali (2016), uji koefisien determinasi bertujuan untuk mengukur seberapa jauh kemampuan model dalam menerangkan variasi variabel dependen. Nilai koefisien determinasi adalah antara nol dan satu. Nilai $\mathrm{R}^{2}$ yang kecil menunjukkan bahwa kemampuan variabel-variabel independen dalam menjelaskan variabel dependen amat terbatas. Klasifikasi koefisien korelasi tanpa memperhatikan arah adalah sebagai berikut:

1. 0 : Tidak ada korelasi

2. $0-0,49$ : Korelasi Lemah

3. 0,5 : Korelasi moderat

4. 0,51-0,99: Korelasi Kuat

5. 1: Korelasi sempurna

\section{HASIL PENELITIAN DAN PEMBAHASAN}

\section{Uji Statistik F}

Berdasarkan tabel hasil analisis deskriptif, tabel 1 menunjukkan bahwa terdapat 232 yang telah mengisi kuesioner dan hasil tersebut diolah untuk mengetahui mean, minimum, maksimum, dan standar deviasi pada penelitian ini

Tabel 1. Hasil Analisis Deskriptif

\begin{tabular}{cccccc}
\hline & N & Mean & Minimum & Maksimum & Standar Deviasi \\
\hline Financial Knowledge & 232 & 14.491 & 7 & 20 & 2.741 \\
Financial Attitude & 232 & 20.391 & 6 & 25 & 3.101 \\
Financial Behavior & 232 & 18.538 & 8 & 25 & 3.380 \\
Keputusan Investasi & 232 & 19.301 & 9 & 25 & 3.600 \\
\hline
\end{tabular}

Sumber: Data diolah oleh peneliti (2020) 


\section{Hasil Uji Normalitas}

Tabel 2. Hasil Uji Normalitas

\begin{tabular}{cc}
\hline $\mathrm{N}$ & 232 \\
\hline Signifikansi (2-talled) & .224 \\
\hline Sumber: Data diolah oleh peneliti (2020)
\end{tabular}

Berdasarkan hasil uji normalitas di atas, hasil penelitian diolah menggunakan teknik Kolmogorov-smirnov untuk mengetahui normal atau tidak distribusi pada penelitian ini. Dapat disimpulkan bahwa penelitian ini berdisitribusi normal sebab signifikansi pada uji normalitas $>0.05$.

\section{Hasil Uji Multikolinieritas}

Tabel 3. Hasil Uji Multikolinieritas

\begin{tabular}{|c|c|c|}
\hline Model & Tolerance & VIF \\
\hline Financial Knowledge & .813 & 1.321 \\
\hline Financial Attitude & .716 & 1.396 \\
\hline
\end{tabular}

Berdasarkan tabel di atas, hasil uji multikolinieritas dilakukan untuk mengetahui ada atau tidaknya multikolinieritas pada sebuah penelitian. Peneliti mengelola menggunakan SPSS untuk penelitian ini dan hasil pada penelitian ini menunjukkan tidak adanya multikolinieritas pada penelitian ini, sebab Tolerance pada penelitian ini $>0.1$ dan $\mathrm{VIF}<10$. Dapat disimpulkan bahwa tidak adanya multikolinieritas pada ketiga indikator tersebut.

\section{Hasil Heteroskedastisitas}

Pada gambar di atas, data diolah oleh peneliti untuk mengetahui adanya heteroskedastisitas atau tidak dengan menentukan apakah pada sebuah model regresi terjadi ketidaknyamanan varian dari residual dalam suatu pengamatan ke pengamatan lainnya. Berdasarkan hasil tersebut, tidak terdapat heteroskedastisitas karena tidak terdapat pola tertentu.

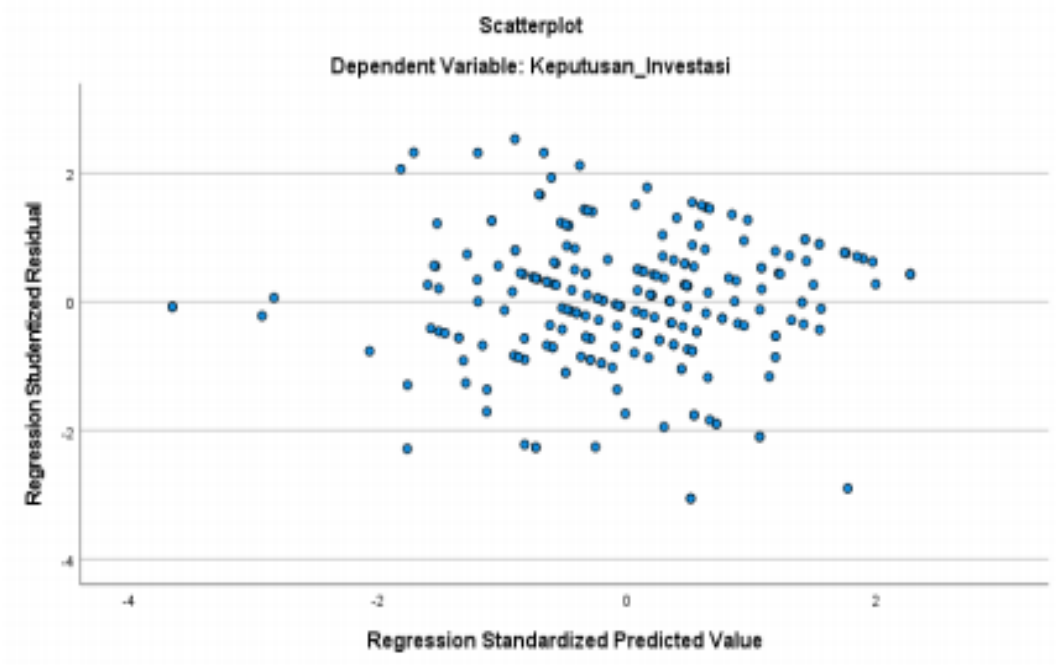

Gambar 2. Hasil Heteroskedastisitas

Sumber: Data diolah oleh peneliti (2020) 


\section{Hasil Uji T}

Tabel 4. Hasil Uji T

\begin{tabular}{ccc}
\hline Model & Koefisien Beta & Signifikansi \\
\hline (Constant) & 4.947 & 0.001 \\
Financial knowledge & .269 & 0.001 \\
Financial attitude & .292 & 0.000 \\
Financial behaviour & .243 & 0.001 \\
\hline \multicolumn{2}{c}{ Sumber: }
\end{tabular}

Sumber: Data diolah oleh peneliti (2020)

Tabel di atas diolah menggunakan SPSS oleh peneliti. Berdasarkan tabel di atas Hasil Uji T yang dilakukan oleh peneliti dengan menggunakan 232 responden The Jak Mania yang telah ditentukan kriterianya. Pada ketiga indikator tersebut dapat disimpulkan bahwa terdapat pengaruh variabel independent terhadap variabel dependen sebab nilai signfikansi ketiga indikator tersebut $<0.05$.

\section{Hasil Uji F}

$\frac{\frac{\text { Tabel 5. Hasil Uji F }}{\text { F }}}{\text { Regression } 30.937}$

Tabel di atas diolah menggunakan SPSS oleh peneliti. Berdasarkan tabel di atas Hasil Uji F yang dilakukan oleh peneliti dengan menggunakan 232 responden The Jak Mania yang telah ditentukan kriterianya. Pada ketiga indikator tersebut dapat disimpulkan bahwa terdapat pengaruh variabel independen terhadap variabel dependen sebab nilai signifikansi ketiga indikator tersebut $<0.05$.

\section{Koefisien Determinasi (Adjusted $\mathbf{R}_{2}$ )}

Tabel 6. Koefisien Determinasi

\begin{tabular}{lll}
\hline $\mathrm{R}$ & $\mathrm{R}$ Square & Adjusted R Square \\
\hline .538 & .289 & .280 \\
\hline \multicolumn{3}{c}{ Sumber: Data diolah oleh peneliti (2020) }
\end{tabular}

Berdasarkan pada tabel diatas diolah menggunakan SPSS oleh peneliti menggunakan 232 responden The Jak Mania yang telah ditentukan kriterianya. Pada pengelolaan koefisien determinasi Adjusted $\mathrm{R}^{2}$, nilai pada $\mathrm{R}^{2}$ adalah 0.280 . Hal ini menunjukkan bahwa korelasi literasi keuangan tidak berpengaruh karena lemahnya korelasi variabel dependen literasi keuangan terhadap keputusan investasi. Maka dari itu, terdapat faktor lainnya yang dapat membantu penelitian selanjutnya karena $\mathrm{R}^{2} 0.280$, maka terdapat faktor lain sekitar 0.72 untuk membantu memperkuat penelitian ini

\section{KESIMPULAN DAN SARAN}

\section{Kesimpulan}

Berdasarkan penelitian yang dilakukan peneliti dengan judul "Pengaruh Literasi Keuangan The Jak Mania pada saham Initial Public Offering PT. Persija Raya Jakarta” dapat disimpulkan sebagai berikut: 
1. Financial knowledge berpengaruh positif dan signifikasi terhadap keputusan investasi The Jak Mania. Uji T menunjukkan nilai positif pada variabel yang menunjukkan bahwa Financial knowledge berpengaruh positif pada uji T. Nilai signifikasi yaitu $0.000<0,05$ diketahui bahwa variabel literasi keuangan berpengaruh siginfikan terhadap keputusan investasi The Jak Mania.

2. Financial attitude berpengaruh positif dan signifikasi terhadap keputusan investasi The Jak Mania. Uji T menunjukkan nilai positif pada variabel yang menunjukkan bahwa Financial attitude berpengaruh positif. Nilai signifikan berpengaruh siginfikan terhadap keputusan investasi The Jak Mania. Nilai signifikasi yaitu $0.000<0,05$ diketahui bahwa variabel literasi keuangan berpengaruh siginfikan terhadap keputusan investasi The Jak Mania

3. Financial behaviour berpengaruh positif dan signifikasi terhadap keputusan investasi The Jak Mania. Uji T menunjukkan nilai positif pada variabel yang menunjukkan bahwa Financial behaviour berpengaruh positif. Nilai signifikasi yaitu $0.000<0,05$ diketahui bahwa variabel literasi keuangan berpengaruh siginfikan terhadap keputusan investasi The Jak Mania.

4. Koefisien determinasi Adjusted R2, nilai pada R2 adalah 0.280. Hal ini menunjukkan bahwa korelasi literasi keuangan tidak berpengaruh karena investasi. Maka dari itu, terdapat faktor lainnya yang dapat membantu penelitian selanjutnya karena R2 0.280, maka terdapat faktor lain sekitar 0.72 untuk membantu memperkuat penelitian ini.

\section{Saran}

Dari hasil penelitian ini, maka peneliti memberikan beberapa saran sebagai berikut:

1. Bagi The Jak Mania

Hasil penelitian ini menunjukkan berdasarkan data kuesioner yang diperoleh oleh peneliti, masih banyak responden yang masih belum sadar akan literasi keuangan. Saran peneliti adalah mengembangkan hal dalam membuat anggaran pengeluaran, mencatat pemasukkan dan pengeluaran keuangan, mengelola keuangan dan faktor lain untuk membantu responden agar membuat keputusan investasi dengan informasi yang dibuat berdasarkan pengetahuan, sikap, dan perilaku finansial dalam keputusan investasi agar membuat keputusan dengan baik.

2. Bagi Persija Jakarta.

Literasi keuangan yang belum memadai diperlukan adanya edukasi mengenai literasi keuangan agar The Jak Mania bisa sadar akan pentingnya pengetahuan keuangan. Persija bisa bekerja sama dengan Otoritas Jasa Keuangan agar membantu The Jak Mania dengan baik mengambil keputusan dengan literasi keuangan yang baik. Hal ini bisa diterapkan melalui sosial media Persija Jakarta yang mempunyai pengikut yang banyak dan juga bisa memberikan campaign dalam tiap laga Persija Jakarta pada saat istirahat, tentunya dengan konten yang menarik agar The Jak Mania bisa tertarik menonton hal itu di papan skor dan bisa mengerti penyampaian yang diberikan dalam campaign edukasi yang diberikan Persija Jakarta agar The Jak Mania bisa berpartisipasi dalam Initial Public Offering serta setelah saham perdana agar bisa 
Mahendra, T. \& Prasetyo, A. H. (2021). Pengaruh Literasi Keuangan terhadap Keputusan ....

membantu dana untuk Persija Jakarta dan mendapat keuntungan dengan adanya permintaan saham dan deviden yang diberikan oleh perusahaan. 


\section{DAFTAR PUSTAKA}

Arikunto. (2006). Prosedur Penelitian Suatu Pendekatan Praktek. PT. Rineka Cipta: Jakarta

Asra, Abuzar dan Prasetyo, Ahmad. (2015). Pengambilan Sampel dalam Penelitian Survey. Rajawali Pers: Jakarta

Besri, O. A. (2018). Pengaruh Financial Attitude, Financial Knowledge, dan Locus of Control Terhadap Financial Management Behavior Mahasiswa S-1 Fakultas Ekonomi Universitas Islam Indonesia Yogyakarta. Skripsi. Program Studi S1 Jurusan Manajemen Universitas Islam Indonesia.

Ghozali, Imam. (2012). Aplikasi Analisis Multivariate dengan Program IBM SPSS. Cetakan Keenam. Semarang: Badan Penerbit Universitas Diponegoro

Ghozali, Imam. (2016). Aplikasi Analisis Multivariete Dengan Program IBM SPSS 23. Edisi 8. Semarang Badan Penerbit Universitas Diponegoro.

Otoritas Jasa Keuangan (OJK). (2017). Strategi Nasional Literasi Keuangan Indonesia (Revisi), Otoritas Jasa Keuangan, Jakarta.

OECD. (2017). G20/OECD INFE Report on Adult Financial Literacy In G20 Countries.

Pertiwi, M. M. (2018). Pengaruh Financial Literacy dan Faktor Demografi Terhadap Keputusan Investasi Mahasiswa. Yogyakarta: Universitas Islam Indonesia.

Rasyid Rosyeni. (2012). “Analisis Tingkat Literasi Keuangan Mahasiswa Program Studi Manajemen Fakultas Ekonomi Universitas Negeri Padang”. Jurnal Kajian Manajemen Bisnis, 1(2): 91-108

Sasono, F. dan Tri Adi. (2020). Persija Optimis Bakal IPO https://kumparan.com/kumparanbola/persija-optimistis-bakal-ipo 1sf3w68SVhh/full . 9 April $2020(12: 55)$.

Sukardi. (2003). Metode Penelitian Pendidikan Kompetensi dan Prakteknya. Bumi Aksara: Jakarta

Sugiyono. (2010). Metode Penelitian Bisnis (pendekatan kuantitatif, kualitatif, dan R\&D). Penerbit CV Alfabeta: Bandung.

Sugiyono. (2011). Metode Penelitian Bisnis (pendekatan kuantitatif, kualitatif, dan R\&D). Penerbit CV Alfabeta: Bandung. 
Mahendra, T. \& Prasetyo, A. H. (2021). Pengaruh Literasi Keuangan terhadap Keputusan ....

Sugiyono. (2015). Metode Penelitian Bisnis (pendekatan kuantitatif, kualitatif, dan $R \& D$ ). Penerbit CV Alfabeta: Bandung.

Tunggal, A. W. (2016) Memahami Pasar Modal Pasca UU OJK. Jakarta: Harvarindo.

Wagland. S . P dan Taylor. S. (2009). "When it comes to financial literacy, is gender really an issue?.", Australian Accounting, Business and Finance Journal 3 (1): 19-20. 